\title{
INTRACUTANEOUS INJECTION OF ACIDOMYCIN IN THE TREATMENT OF LEPROSY
}

\author{
Yukichi SATANI \\ (Emeritus Proffessor of Osaka Univ. Med. School, Director of Osaka National Hospital) \\ Shinji NISHIMURA, Tonetaro ITO \\ (Osaka Dermatological Institute, Osaka University) \\ Taiji NOJIMA, Mutsuo MORIYA, Takeyo TAKAHASHI, Motoko UEMURA \\ (National Leprosarium, Oshima Seishoen) \\ Hosaku SAKURAI, Kazuo SAIKAWA, Tokuzo YOKOTA \\ (National Leprosarium, Nagashima Aiseien) \\ Matsuki MIYAZAKI, Osamu HATA \\ (National Leprosarium, Kikuchi Keifuen) \\ Yoshinobu HAYASHI, Makoto HIRAKO \\ (National Leprosarium, Tama Zenshoen) \\ Yutaka KAMIKAWA, Akira WATANABE \\ (National Leprosarium, Tohoku Shinseien)
}

The therapeutic results of intracutaneous injection of Acidomycin in leprosy has been reported previously (La Lepro, Vol. 24, No. 3, June 1955, Internat. J. Leprosy, Vol. 23, No. 2, 1955). Treatment with this agent, has been continued at various institutions, for various lengths of time, 3 6 months at the shortest, 4 years at the longest, and the results are presented here.

The total number of cases treated was 129 , including 88 cases of lepromatous leprosy and 41 cases of macular leprosy (some neural type included). The greatest effect was observed in the macular type, the majority of those responding be longing to this group, while only a few of the lepromatous type showed a response. It is noteworthy that improvement in the sensory disturbance and lessening of the neural thickening took place with long-term treatment.

The mechanism of action of this agent has not been adequately clarified but from the findings that intramuscular injection of Acidomycin has no effect and intracutaneous injections of streptomycin and INAH are ineffective it is suggested that Acidomycin acts specifically on the host tissue rather than acting as a typical chemotherapeutic directly on the leprosy bacilli. 


\title{
Acidomycin の皮内注射による瀬の治験 (第 2 報)
}

\author{
佐谷有吉 \\ 大应大学徽生物病研究所 西村真二・伊藤利根太郎 \\ 国立療養所 大島青松園 等島泰治・守屋睦夫・高橋竹代・植村新子 \\ 国立療養所 長島愛生園 桜升方策・犀川一天・横田篤三 \\ 国立寮養所 菊池恵㮯圆 椬崎松記・波多 治 \\ 国立療養所 多等全生園 林 若信・平子 真 \\ 国立寮養所 東北新生園 上小 豊・浸辺 昭
}

(昭和 33 年 2 月 10 日受稿)

$\because$ 大阪大学名誉教授，国立大阪病院長

緒咅

私どもは，さきに Acidomycin の皮内注射による瀨の 治療効果について予報した（レプラ第 24 卷 3 号, 昭和 30 年 7 月)。今回はその後の成績について報告する。実 施場所は, 大島青松園, 長島愛生園, 料池㯖楓園, 多整 全生園，東北新生園の 5 力所で，それぞれ表記の担当医 官によつて行わ机た。

本戍定皮内注射の形で使用した原理についてはここの

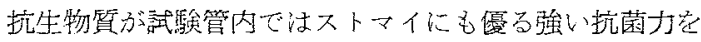
示寸に斿斿らず，生体内で活ビオチンの拮抗作用によ つて殆んど無力化するという説にもとずき，先ずどオ千 ソの拮摭をできるだけ避䏠たい意味で，体溜交流の比较

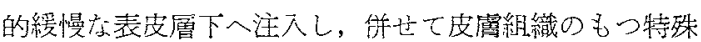
の抵抗力を刺战元進世し的上うとの放らいに出たもので

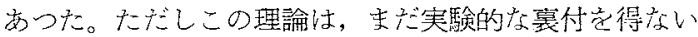

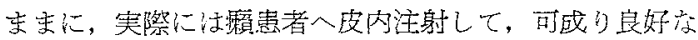
結果得たので亦る。

そこでわ机わ杖この察実にもとざいて，更に各病型 について，長期間に亘り本戍の効果索観察与ると共に，

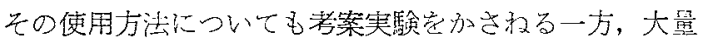
筋肉内注射法, 他の抗菌偊による皮内注射法など対照的 な治駼例をも得たので以下こ㣗らの成績をとりま之的， 第 2 報として報告与る次第である。

\section{実 験 方 法}

前報記載の如く武田薬品工業株式会社研究所において
抽出精製されたアシドマイシンの per c.c 20〜40〜50

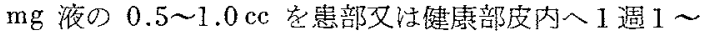
3 回の割合で注射した。本治療の継続期間及び他の蔡剂 との併用は，患者の病勢に応じて決定せられた。

病型注従来の如く結節型 $(\mathrm{L})$, 斑紋型 $(M)$, 神経型 （N）とした。効果の俨価恃著効，中効，少効，無効と

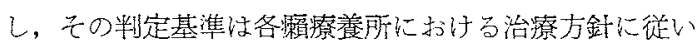
任意に定められたものである。

\section{1 皮内注射法による長期の治療成績}

\section{1）大島青松園における治験}

本園では1953 年 1957 年の間, 43 名の患者汇ついて 試攵大。男 29 ，女 14 年命は 13〜 68才，病型は L 23 名（ $\left.\mathrm{L}_{1} 11, \mathrm{~L}_{2} 9, \mathrm{~L}_{3} 3\right) \mathrm{M}$ (N空含点) 20 名で亦口 た。発病後の経過年数㳉，I年以内 $4 ， 1 ５$ 年. 14，5 10 年 10,10 年以上ダ 15 名で経過の短いものは斑敘型 に多く，10 年以上の長いもの法多く結節淮及び 神経缜 であつた。患者活本治療前に，大風子油，プロミン其の 他のスルホン剂，INAH，チビオンなどによる治療を受 けたこと勿諭で京るが，副作用其の他によつてこ礼が継

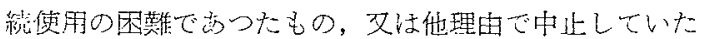
ものが多く，少数例では入園後未治潦のむのて京つた。 成綪俚表工の通り。

6 カ月以队の 8 例では，注射の少いものた 12 回，多

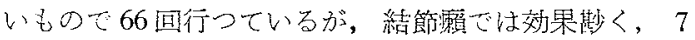

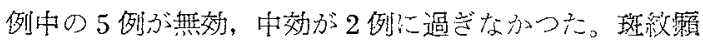
ではI例が少効の程度であつた。 
表 1

\begin{tabular}{|c|c|c|c|c|c|c|c|c|c|}
\hline \multirow{2}{*}{ 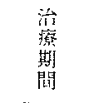 } & \multirow{2}{*}{$\begin{array}{c}\text { 結 } \\
- \\
\text { 䓪 }\end{array}$} & \multicolumn{2}{|c|}{ 節 } & \multirow{2}{*}{ 钴 } & \multicolumn{4}{|c|}{ 斑紋痽（N女含む） } & \multirow[b]{2}{*}{ 訫 } \\
\hline & & 效] & 少 & & $\begin{array}{l}\text { 蓍 } \\
\text { 效 }\end{array}$ & 市 & 尖 & 橆 & \\
\hline $3 \sim 6$ 月 & & 2 & & 5 & & & I & & 8 \\
\hline $6 \sim 12$ 月 & 3 & 2 & 2 & 4. & 5 & 2 & 2 & 3 & 23 \\
\hline $1 \sim 2$ 年 & 1 & i & & 2 & 2 & & & & 6 \\
\hline $2 \sim 3$ 年 & & & I & & 1 & & & & 2 \\
\hline $3 \sim 4$ 年 & & & & & 3 & 1 & & & 4 \\
\hline 訣 & 4 & 5 & 3 & 11 & 11 & 3 & 3 & 3 & 43 \\
\hline
\end{tabular}

6〜12 カ月治療を続けたものは，L11，M 12 計 23 名 で全例の大半を占めている。そしてこの期間に尠くて 48 回, 多いもので 126 回注射定絖けている。效果注

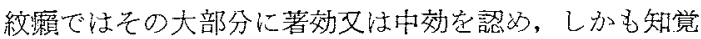
の快復したものが5例に上つている。そして無效 3 例で あつた。結節櫴では 7 例が著效万圣少効で，4例が無効 であつたが，しかし著经例ではの中にはこの状態壳く 持続子ること困難で，そのため他の薬鼡に䎐換或はをれ と併用したものが多い。

1ケ年以上治療を継繶したもの12例では10例に良効

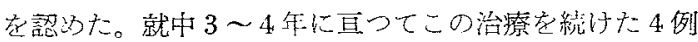
忹いずれも丵效例であつた。

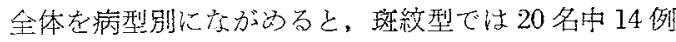
が奏効し，中には知覚の快復著睤であつたもの11例。

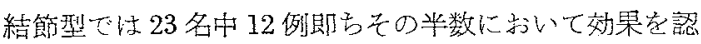
わたのみである。以下医期治療並に特別な症例について 記載等る。

1) 㑟 $\mathrm{O}$ 利: 男, 17 才, 1953 年発病, 病型 $\mathrm{M}$, 兩湏 部に定型的な結核棁斑敉，両側大耳神経珠数状肥厚，菌

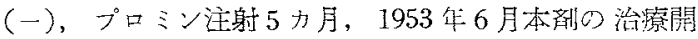
始, 1957 年 10 月末てに 369 回 $11,185 \mathrm{mg}$ 便用

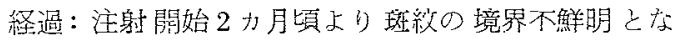

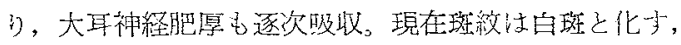

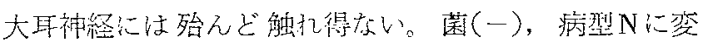

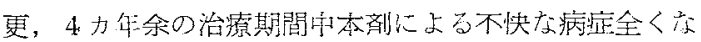
L。(Fig. 1, 2)

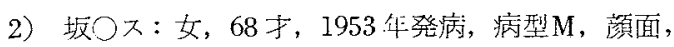

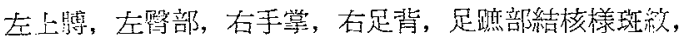
藏(一), プロミン注射 2 力月，1953年10月より本胱の

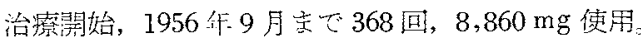

程過：注射開始後 2 力号各部の班紋は褪色，知覚当著

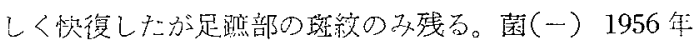
4月Schub总起したが再心゙吸収，現在他の薬洲に転換， 蒋効。
3）木○倉：男, 55 才, 1942 年発病, 病型 $\mathrm{N}$, 背部, 胸部に広い白斑とその部知敩脱失，菌 $($ 一)，プロミン注 射 6 力月，1953年10月より本治療開始，1953 年 10 月 东でに293回，10,380 mg 使米。

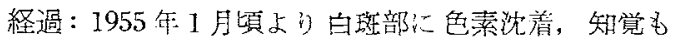

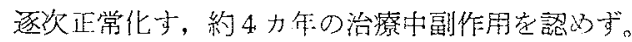

4) 大 $\mathrm{O}$ 一: 票, 30 才, 1954 年発病, 病型 $\mathrm{M}$, 左在 肘部に広、結核栏璒紋，闭側尺骨袖経肥厚，菌(一)，プ マトゾール，涊ル，ストマイ，INAHて 2 カ月治 療，1955年 2 月本治療に入り，1956年 11 月軽快退院ま で 1 年 9 力月に 242 回, $5,990 \mathrm{mg}$ 使用。

経過：1力月㖽より斑級隆起部消退，尺骨神経肥厚の

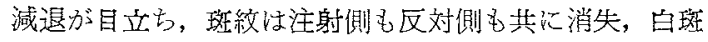
となり後健康色以快復, 1 力年後に知㥯快復毛再生, 1956 年 11 月退園, $\mathrm{N}$ 型と守。

5）青 $\bigcirc$ 昌: 男, 27 才, 1955 年発病, 病型 $\mathrm{M}$, 顔面, 項, 背, 胸, 両上肢下肢の各部に隆起せる著朋な紅色斑 䣄あり，胸部，背部のものは一部の辺緑隆起し表皮の糜

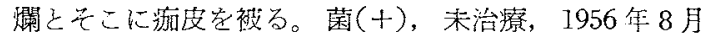
より本治潦關始，1957 年11月末でに 377 回，13165 mg 使用。

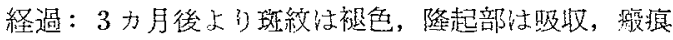
形成，一部に白斑空残与。知觉もこ机化佯つ快復，7 ケ月後現在毛再生N型。長期の治療中光不快な症状空認

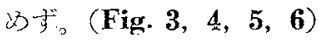

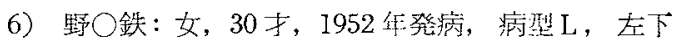

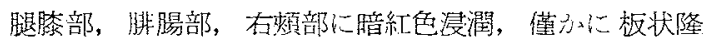
起, 菌(十)，プロミン 6 力月注射，1953年10月上り本 治療閐始，1954年9月まてい174国，4,405 mg 使用。

経過：2力月目に下腿の注射局所及び頓部浸润褪色吸

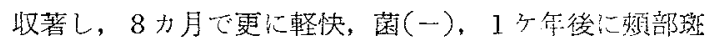

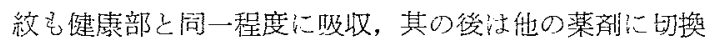
病症軽快持緮。組織所見 (Fig. 19, 20)

7) 中O連: 男, 30 子, 1946 年発㾥, 病型L, 背部

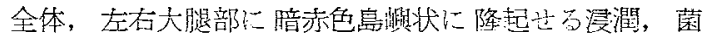

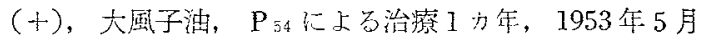
より本治㵔閶始。1955 年6月まで 150 回，4.115 mg 使 用。

経過：6力月後背部の注射局所及他部の浸澗当全般に

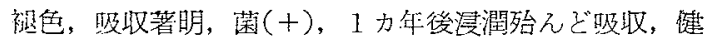
常部とほぼ同檬，菌(一)，1954年10月急性增覀他の蒋 剂併用吸取に傾く。(Fig. 7, 8)

8）須 ○菊：男，31 子，1941 年発病，病型L，顔面 


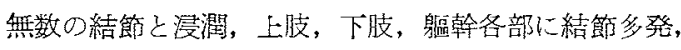
菌(州)，来治療，1954年6月より治療開始，1955 年6 月まで 98 回，2,085 $\mathrm{mg}$ 使用。

経過： 3 力月目で浸潤稍々消遇，菌(H)，10力月で は颜面の浸潤，結節は可成り吸収，石前膊注射局所孔级 取著明，菌(甘)，其の後症状の改善它見ず，プロミン併 用によつて逐次軽快。(Fig. 9, 10)

9）三○熊：男，64f，1910年発病，病型M，背部 全体に大きい褐色班放，僅かに隆起し，菌(一)，1953年 10 月より背部斑皎部入注射開始，1953年 3 月をでに 114 回, $2,830 \mathrm{mg}$ 使用。

経過：2力月後斑絔部の皮膚洛展，8力月で褐色調も 殆えど消褪，隆起僅ふに残る。1 年後症状に变化なし， 他の薬風に転换少効。組織所見（Fig. 21，22）

\section{2）長島愛生園における治験}

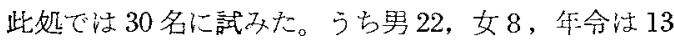
寸〜71 子に亘る。病型は全部結節型で $\mathrm{L}_{2-3}$ という比較 的重症なものが選ばれ，発病後 10 年以上学経過せるも のが 20 名，あとは 2 年以上である。この間大風子油は 㭁論プロミンなどのスルホン郕やINAH 索投与してい

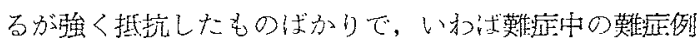
であつた。

治療战績の総括は表 2 に示した。

衾2

\begin{tabular}{|c|c|c|c|c|}
\hline \multicolumn{2}{|c|}{ 䜌 } & 節 & 95 & \\
\hline 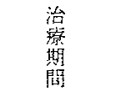 & 效 & 1) & 重 & 竐 \\
\hline $2 \sim 65$ 月 & 1 & 4 & 2 & 7 \\
\hline $6 \sim 12$ 个月 & 2 & 5 & 8 & 15 \\
\hline $1 \sim 2$ 年 & 2 & 1 & & 3 \\
\hline $2 \sim 3$ 年 & 5 & & & 5 \\
\hline 計 & 10 & 10 & 10 & 30 \\
\hline
\end{tabular}

継㿠して治療6力月以内のもの7例，6〜12 力月が 15 例， $1 \sim 2$ 年が 3 例， $2 \sim 3$ 年が 5 列である。いずれも 注射開始 $3 \sim 4$ 力月て結節浸溜は可䇅り消退して局所の

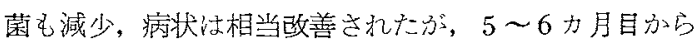
多くの列に䄧いて再び顔面，四肢に浸溜学るようにな つた。かして治療在中断した例が続出したが，この場 合DD S其の他の薬剂に切換えて一定期間喷に再間する か文はこ秃等と併用したものでは良效起持続することが 出来た。

副作用については殁えど認すべきものがなかつた。即

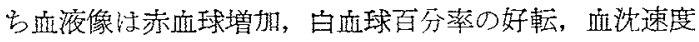

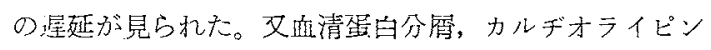

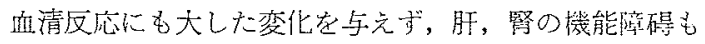
認心ない。Biopsy では結節消退時において菌の隇少变 形並に結合織の増生が見られたが，然し組織学的には， Leproma の消失という段階には全らない。又 E L の

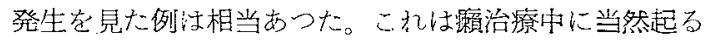
現象でアシドマイシンの副作用と見做すわけにはいか ぬが，本刜の場合はプロミンなどに比してやや軽かつ た。

以下長期間本凪を注射した症例について記逢する。

1）山O勝: 男, 33 才, 1939 年発病, 病型 $\mathrm{L}_{3}$, 愐及

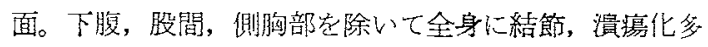
し。菌(H), 大風子油, プロミン,プロトゾールにて治 療したが效なく，1954年 7 月本洲注射開始，1957 年 11 月をで 3 年 4 カ月で 243 回, $6,075 \mathrm{mg}$ 它使用。

経過： 3 力月目漬瘍治瘾著し。菌(H), 6 力月で再

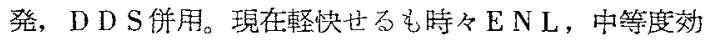
あり。

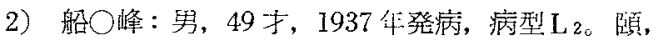
前膊, 太腿に結節散発, 菌 $(H 甘)$ 。大風子油, プロミン, INAH にて治療。1954年10月より本威这射開始，1957 午11月までに126回, 2,875 mg 便用。(Fig. 11, 12)

経過：1力月後から結節消退し知的，3力月で著しく 消失, 以後同一D病状保持, 菌 $(+)$, 現在軽快, 副作用 なし。等度效あり。

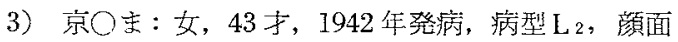
紅く腫脹浸潤，結節散在，プロミン治潦 2.5 年，菌(H) 1954 年 10 月本剂の注身開始，1957年11月宋でー200 回, 5,000 mg 使用。(Fig. 11, 12)

程過：注射简始 1 力月で著しく腫脹隇退，10力月て 腰部に結節新生したがチビオン伤用，以後軽快，菌(十) 中等度効方り。(Fig. 13, 14)

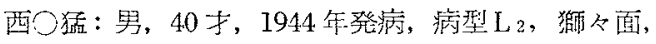
顔面大結節密発，四肢腰部に結節多発，菌(装)，1955 年 1 月上り本剂注射開始，1957 年11月灾で 244 回， $6,100 \mathrm{mg}$ 便用。

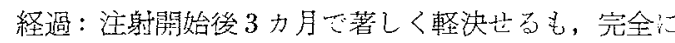

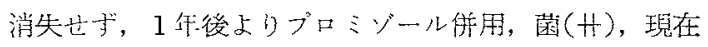
相当㪕快，副作用なし，中等度效あり。(Fig. 15, 16)

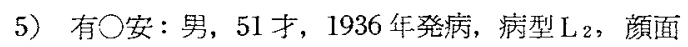
及び四肢に軽い浸潤，菌(十)，大風子油，スルホン剂に よつて症状軽決せるる副作用に不安のため，1955年本 刜注射開始，1957 年11月まで112回，2,800 mg 使用。

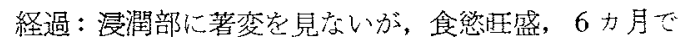


体重增加, 神経痛消失, 知党快復, 年等度效亦门。

\section{3）菊池惠楓園における治験}

ここでは䛨 21 名心試みた。このうち男 12 , 女 9 , 絬 節型 $\left(\mathrm{L}_{1} \sim \mathrm{L}_{3}\right) \quad 7$ 名, $\mathrm{M}(1 \sim 3) 14$ 名で, 発病I年以

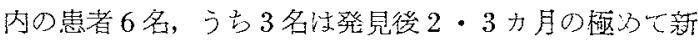
らしいM.T患者であつた。市との15名中 9 名方 5 年

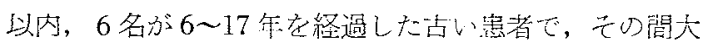
風子油河諭，プロミン，DDS，プロミゾールなどが 用いられたことは帚う实で舟ない。

成䋹の総括住表 3 の和く。

\section{表 3}

\begin{tabular}{|c|c|c|c|c|c|c|c|c|c|}
\hline \multirow{2}{*}{ 治 } & 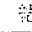 & & & 䫅 & 湤 & & & 24: & \multirow[b]{2}{*}{ 詮 } \\
\hline & 簿 & $\begin{array}{l}\text { म5 } \\
\text { 就 }\end{array}$ & 少析 & 的 & 菱 & 站 & 劣 & 年 & \\
\hline 6月志て & & & & 1 & 1 & 2 & 1 & 1 & 6 \\
\hline $7 \sim 12$ 月 & & 1 & & 1 & & 1 & 2 & & 5 \\
\hline $1 \sim 2$ 完 & & & & 3 & & $I$ & & 2 & 6 \\
\hline $3 \sim 4$ & & I & & & 3 & & & & 4 \\
\hline it & 0 & 2 & 0 & 5 & 4 & 4 & 3 & 3 & 20 \\
\hline
\end{tabular}

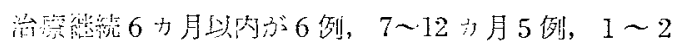

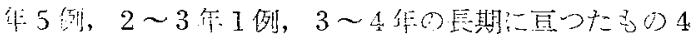

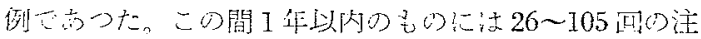

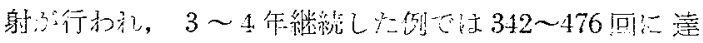
してい,

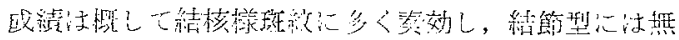

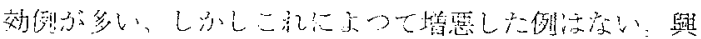

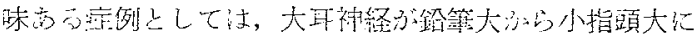

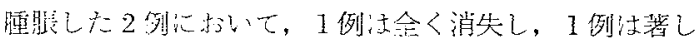

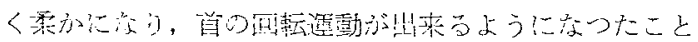

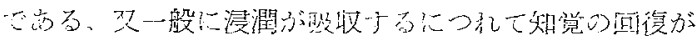

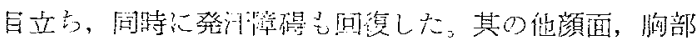

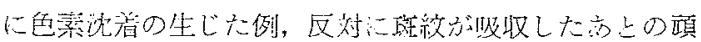

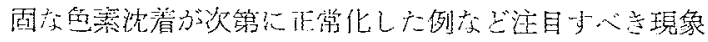
とい文方。

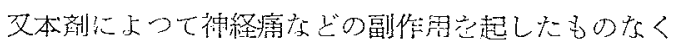

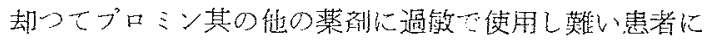

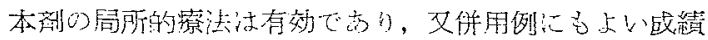
艾得た。

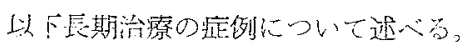

1) 高门智: 男, 46才, 1954 年登病, 病型 $\mathrm{M}$, 顔面

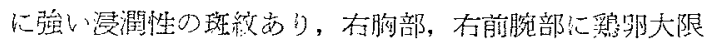

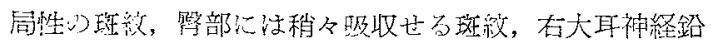
筆大肥学，菌 $(+) ， 1954$ 年 7 月より本詴注射開始，1957 年 10 月枺丈でに 476 回，26,425 mg 使用。

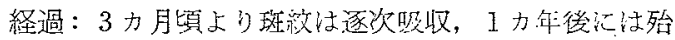
えど消退，神経の肥厚も亦減退した，現在斑吸取部の 知觉快復著し, 藏(一), 和治潦繼㿠, 副作用なし, 著 效。(Fig. 17, 18)

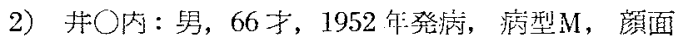

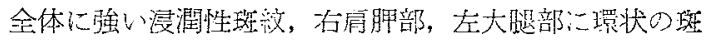

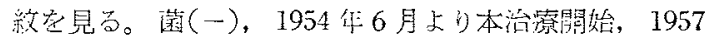

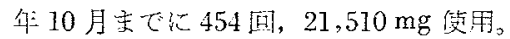

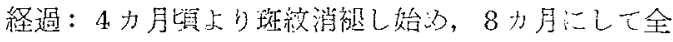

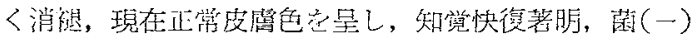

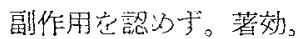

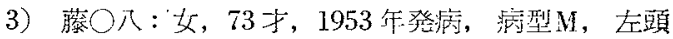

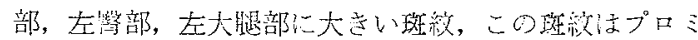

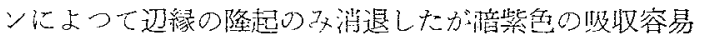

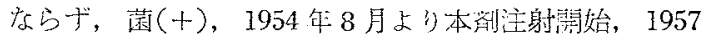
年 3 月宝飞飞 367 回, $17,310 \mathrm{mg}$ 倬间。

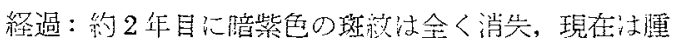

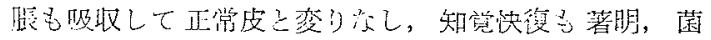

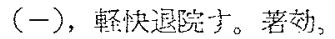

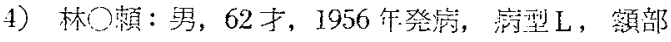

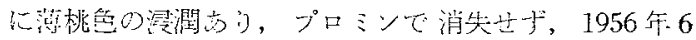

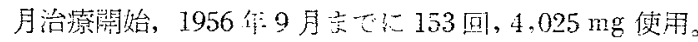

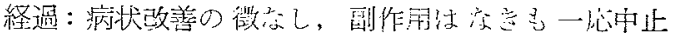
一, 然效。

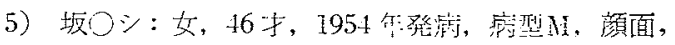

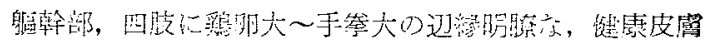

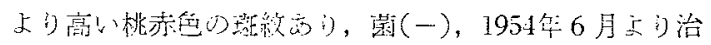

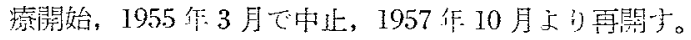

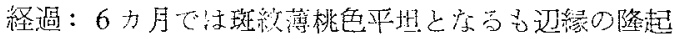

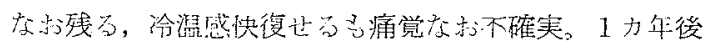

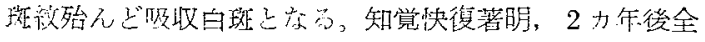

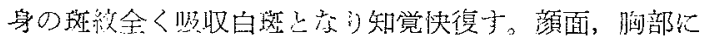

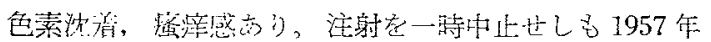
10 月上引再開。中等度效充门。

\section{4）多磨全生園に南ける治験}

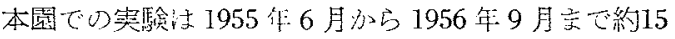

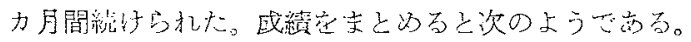

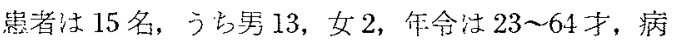

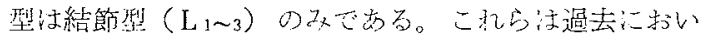
て大風子泊，プロミン，DHDS，チビオン，七フケラン

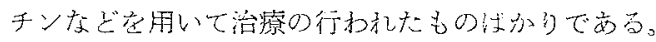

效果は表に示した如く，15例中 8 例儿可或りの效果

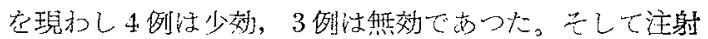

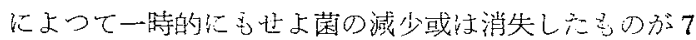


表 4

\begin{tabular}{|c|c|c|c|c|c|c|}
\hline 結 & & & 節 & & 獭 & \\
\hline 治康斯得 & 效 & 少 & 効 & 無 & 効 & 桩 \\
\hline $2 \sim 6 月 !$ & 2 & & 2 & & 1 & 5 \\
\hline $7 \sim 15 \mathrm{H}$ & 6 & & 2 & & 2 & 10 \\
\hline 䛎 & 8 & & 4 & & 3 & 15 \\
\hline
\end{tabular}

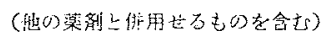

例に上つた，次に比較的臣くこの治療䘮継続した症例を 挙げる。

1）内口不：男，64于，1941 年発病，病型L，1955 年 9 月より約 1 ケ年に 120 回注射，始的顔面急性浸潤で 菌（サ)であつたが，本郕と共にハイドロコーチゾンの併 用によつて一愿よく昅收箸しく軽快, 菌(一)となつた。 中等度効，(他の 2 侄にも八イドロコーチゾンを併用し て良好志収的たもの方り）

2）高门三：男，28 f，1954 年発病，病型L, 1955 任 6 月より翌年 9 月までに 90 回注射。初必肢の一面 に結節在新生し䒩 $(+)$, 注射開始後 E N L 户神経痛定起 し，症状改善され高，無效であった。

其の他與味ある应例としては注射 7 11 回で円形脱毛 症の毛髮再生堂見たもの方４例古つた。

結節癭の子文対象として行つた本園での成績は，比較 的短期間で流るが概して良效を奏したとはいい難く，

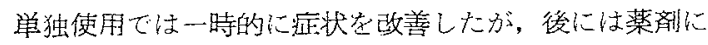
馿机たため效果が举らなからた。の場合一時休莧又 は他の薬刜との併用は有利であつた。

\section{5）東北新生園における治効}

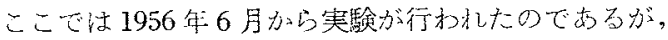

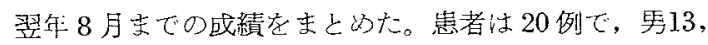
女 7, 年令は 13f〜71子，病型注結節型 ( L 1 3 $) 13$, 斑䊉型 $\left(M_{\text {: 3 }}\right) 7$ であつた。発病後の経過は，1年以 内のもの 5 名, $2 \sim 5$ 㸞が 4 名, $6 \sim 33$ 年 11 名, 最も 新しい症例沈 2 カ肺つた。而してこれらの患者は本 戍によを治療前に多くはプロミン，DDS，ダイドラチ ン， $\mathrm{P}_{3-4} \mathrm{~L}$ 度どの治療花受けているが，全く然処置のも のも4例㚣つた。注射方法海週 1〜2回虫部人行つた。 成續㳉表 5 に示した。

\section{表 5}

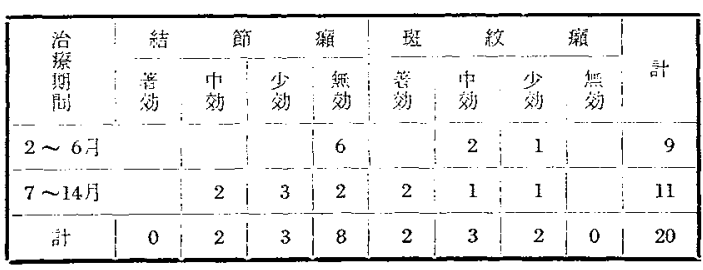

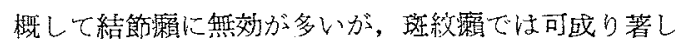
い效果定認好た。特に未治療の新鮮な鲁者において著明 であつた。結節辚においても，注射開始後 10 回目位か ら吸収し始河, 後或る程度末で軽快して菌も減少するが それ以上は奏胶し難い。この場合プロミンを併用してそ の效果宾持続できたものがある。班紋型では 7 例中 5 例

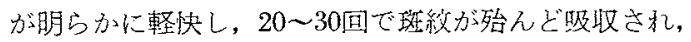
中には知覚の快復したもの3例觉見ることが出来た。稍 々興味ある蜜例としては次のようなものがある。

1） S T：男，53 手，1923 年発病，病型L, 顔面陳 旧性浸潤，菌(十)，脣期プロミン注射。1956年6月よ り本郕の注射開始, 翌年 8 月まてに 138 回, $4,175 \mathrm{mg}$ 使 用。

経過：当初ナシドマイシンのみで治療，浸潤は可成り 著しく消退したが，其の㷋停頓したのでプロミンを併用 現在注逐次軽快に向つている菌(+)变形のもの多し, 中 効。

2）Ｔ０：女， 71 才， 1950 年発病，病型M，背部 に広沉京結核梯斑紋、菌(一), 未治療, 1956年7月よ り本戍注射開始，1957 年 8 月までに 37 回，925 mg 便 用。

経過：3力月目注射 27 回で背部にあつた手堂大の隆

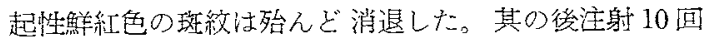
に過ぎないが、再発なく、斑紋は依然として消端の立 である。菌(一)，著効。

3） T I：女， 12 才，1955 年発病，病型M, 颜面贶

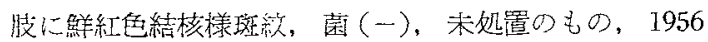
年: 9 月より本剤注射開始, 1957 年 8 月まてに 36 回, $1,150 \mathrm{mg}$ 使用。

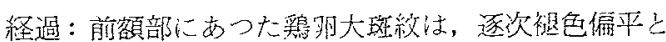
なり，1年目て殆えど完全に消失, 知党も快復, 局所の 注射痛が豩しくなつた。菌(一)，著効。

\section{皮内注射法による治療成績の総括}

上記○ 5 力所で試々た治療成績を総括寸ると, 焦者は

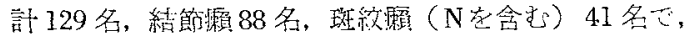

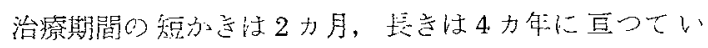
る。これら学病型と治療期間に大別し, 或績定著效, 中 等度効, 少効, 無効に区分してなが沙ると, 次袁の上う

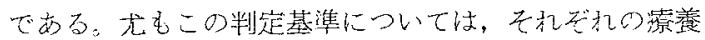

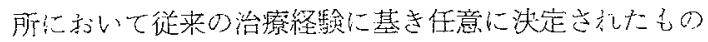
であるから，A療養所の著效がB療養所の著效と必主し も闹一程度であるとは元い難く，徉つて效果別の会尌数

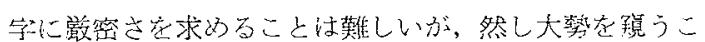


とは出来ると思う。

表 6

\begin{tabular}{|c|c|c|c|c|c|c|c|c|c|}
\hline \multirow{2}{*}{ 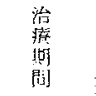 } & 結 & \multicolumn{2}{|c|}{ 䇥 } & 緥 & \multicolumn{2}{|c|}{ 斑 } & & 您 & \multirow[b]{2}{*}{ it } \\
\hline & $\begin{array}{l}\text { 慕 } \\
\text { 㹢 }\end{array}$ & $\begin{array}{l}\text { 桇 } \\
\text { 效 }\end{array}$ & 劣 & 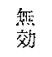 & $\begin{array}{l}\text { 荎 } \\
\text { 效 }\end{array}$ & 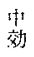 & 少 & 效 & \\
\hline $2 \sim 6$ 月 & & 5 & 6 & 15 & $I$ & 4 & 3 & 1 & 35 \\
\hline $7 \sim 12$ 月 & 3 & 13 & 12 & 17 & 7 & 4 & 5 & 3 & 64 \\
\hline $1 \sim 2$ 年 & 1 & 3 & 1 & 5 & 2 & 1 & & 2 & 15 \\
\hline $2 \sim 3$ 年 & & 5 & 1 & & 1 & & & & 7 \\
\hline $3 \sim 4$ 年 & & 1 & & & 6 & 1 & & & 8 \\
\hline \multirow{2}{*}{ 敦 } & 4 & 27 & 20 & 37 & 17 & 10 & 8 & 6 & \multirow{2}{*}{129} \\
\hline & \multicolumn{4}{|c|}{88} & \multicolumn{4}{|c|}{41} & \\
\hline
\end{tabular}

表で見ると，沿療期間は，7 12力月のものが最も多

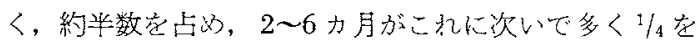
占わている。これらの中には現在なお繼綕治療中のもの がある。1 年以上の症例は計 30 名で，ての多くは有效 で患者の希望によつたものである。一般に結筑俛では著 效索示したもの尠いが，そのうちでも比較䢀新鮮な症例 では可成り奏效した。しかしいずれも一定度末で軽快す 机ば，乙九以上效果定持続することがむいかしく，所詮

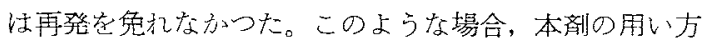
例えば，注射後 $2 \sim 4$ 力月で效果が举れいば，一時注射在

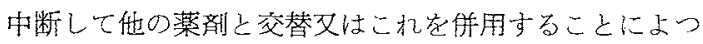

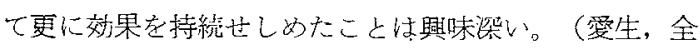
生)、攵この治療間に病葧の增雭したものでは，注射の

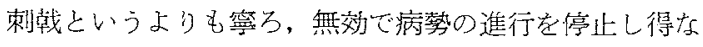
かつたものである。病米中の菌の增減については各所と

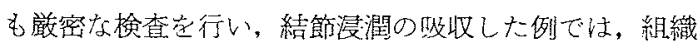
学的に主明らかに細胞浸滓の消褪が証明され，藏の減少 顆粒状变形方檍的ら㣗た。

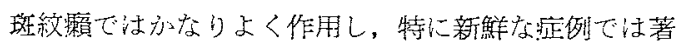

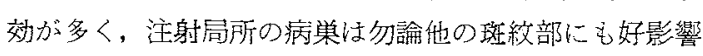
孝与光, 病症の改善に伴つて知覚の快復を見た例が多数 あつた。（青松, 恵楓, 新生）文特異な症例としては大 耳神経の肥厚方，こ侊によつて殆えど触㣗得ないまでに

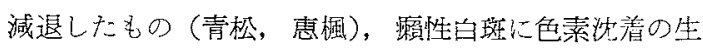

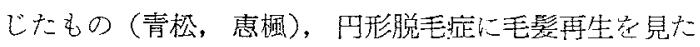
もの（全生）などこ狆また興味ある雪実である。更に本 剂を3〜4年の長期に亘つて用いた患者に抋てを何等 不快な症状学伴わず副作用らしきものさえ詡めなかつた

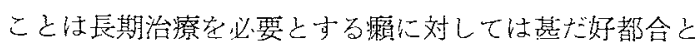
いえるであるう。

\section{Acidomaycin の大量筋注による治療成績}

アシドマイシンの锺量（20５0 mg）週 1 ～2回の皮

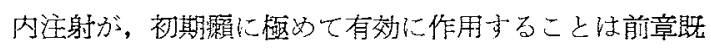
に述べた通りであるが，さてこのメカニズムについては 今のところ亡だ明かでない。

ここに覧筋内大量注射㣻試みた理由は，上述の作用機 転艺解析する1つ0試みともなり, 㕛嬾菌への直接的影 響をほのかに期待したがためである。若し皮層組織を経

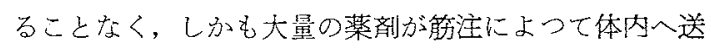

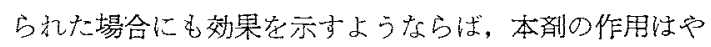
はり直揬に瀨䒩自体への影響艺重視しなけ札ばならぬわ けである。

\section{実験方法}

この注射は大鳥青園に拉いて 1 週 3 回 1 日 $50 \mathrm{mg}$ $1 \mathrm{cc}$ の滅菌蒸溜水に溶解萼筋内人注射し，4䓢間連続， 1 週間休薬これるを1クールとし5クールまで実施した。

\section{実験 成 績}

表7に示すよらにNo.1〜11まではアシドマイシンの

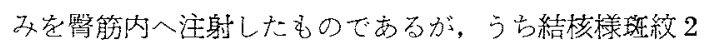
例中の1例に心いて，斑彎消遍の少效を見ただけで，仵

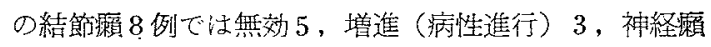
無効 1 だつた。

文DDS，INAH を併用した結節霜 8 例について㫕る

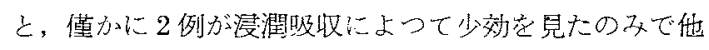
は無效であつた。

即台これによるとナシドマイシンは，たとい大量とい えども笳肉内注射では殆んど反心赤さず，又こ礼に他 の化学療洼倣を併用しても特に效果を高的るようなと はなかつた。

\section{Streptomicin 及び INAH の皮内注射 による治療成績}

この笑瑍は，皮内注射注ならばAcidomycin 以外の抗 菌性物質を以てしても间一の效果が得られるのではなか ろらか，という対照の意味において行つたものである。

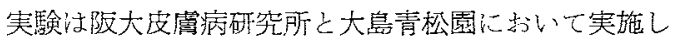
t:。

阪大ては 5 例の患者に1954年 3 月より 8 月に亘りス トマイ壱 $1 \mathrm{cc} ： 166 \mathrm{mg}$ の濃度に洛ふしたもの0.2 cc (33

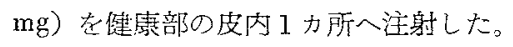

大島青松圆では1954年4月より8月に可つて 3 例に ストマイ老他の3例にはINAH 学注射した。ストマイ

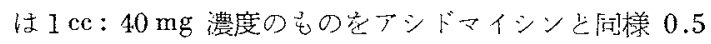
$c c \sim 1 c c$ 学 1 違 $1 \sim 2$ 回患部数力所入皮内注射 L, INAH は $1 \mathrm{cc}: 25 \mathrm{mg}$ の濃度としたもの $0.5 \mathrm{cc}$ 1 cc を 1 遇 1 
Acidomycin の筋肉内注射による治寮成績（1956.2.16７.28）

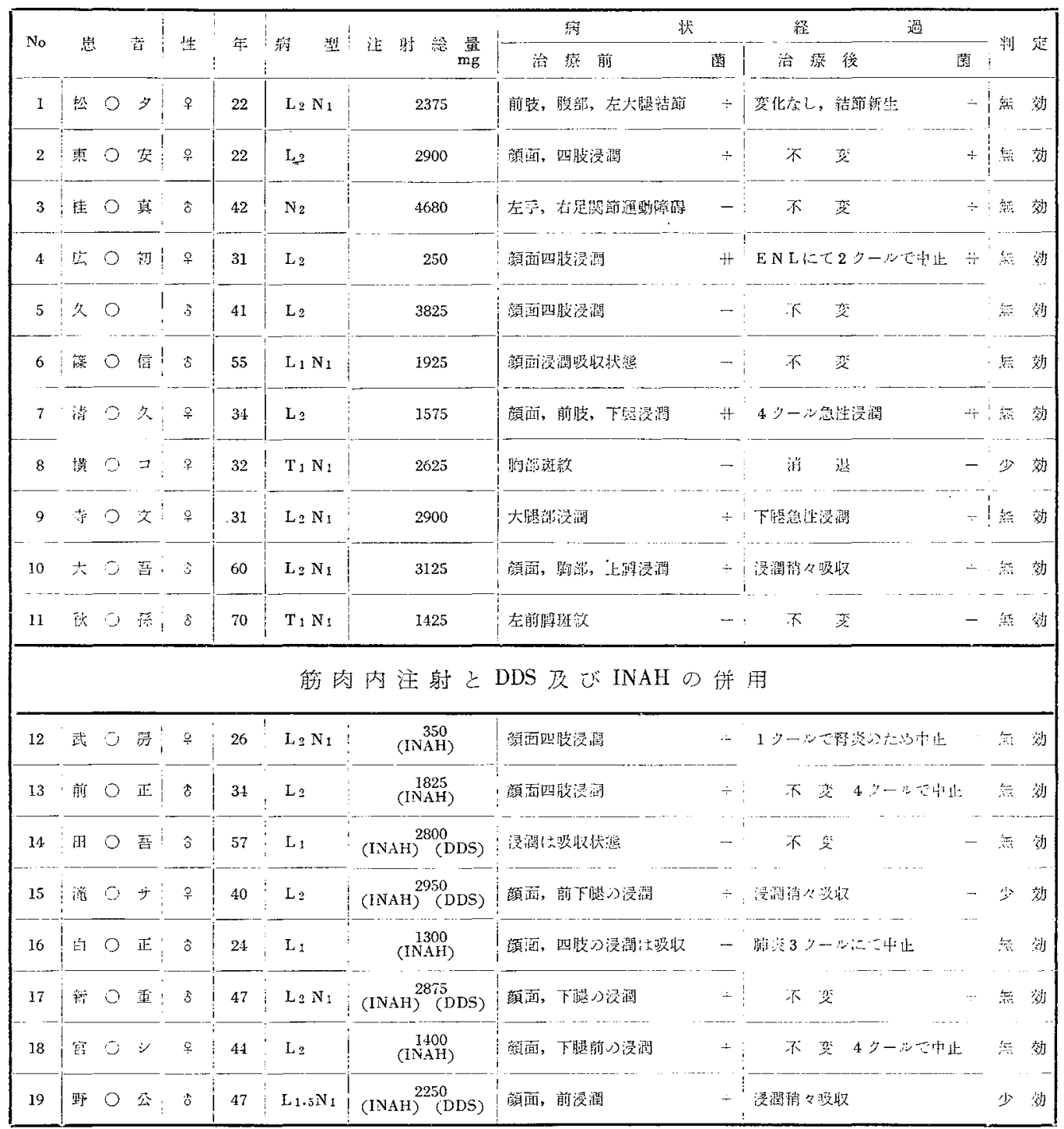

〜2同の割で同様に皮内注射した。

成續は表 8 の如くである。

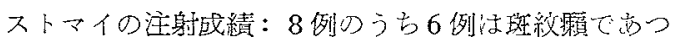

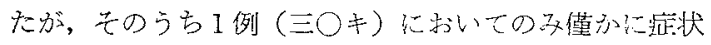

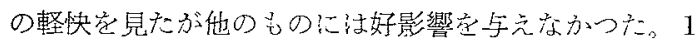
例のL型， 1 例のN型患者にも奏效意見なかつた。大乙

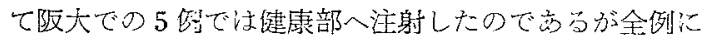
局所の小水有々，癌痒感賞えた。

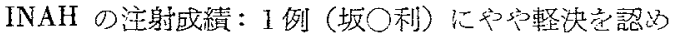

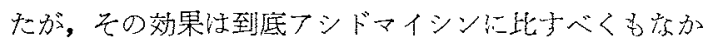
つた。
このよう他他の抗菌物暂定以て皮财注射在䘕つても，

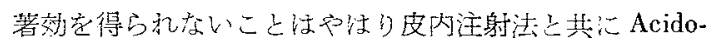

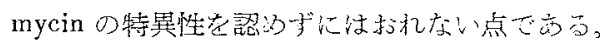

\section{結語}

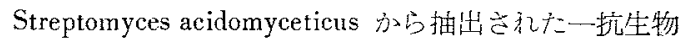

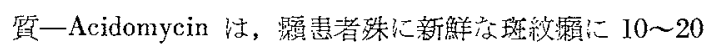
$\sim 50 \mathrm{mg} 1$ 週 $1 \sim 3$ 回皮内注射すれ芯 $2 \sim 3$ カ万で著し く症状が改善さ虬るものが多い。この場合斑新部への注 射によつて先ず局所の病状が軽快するが，遠滑部にも好 影響を与え得る。健度部への注射も亦有效であつた。そし 


\section{表 8}

Storeptomycin 及び INAH の皮内注射による治療成綪

\begin{tabular}{|c|c|c|c|c|c|c|c|c|c|c|c|c|}
\hline \multirow{2}{*}{\multicolumn{2}{|c|}{ 列别 }} & \multirow{2}{*}{ 蚍 } & \multirow{2}{*}{ 苨 } & \multirow{2}{*}{ 性 } & \multirow{2}{*}{$\begin{array}{l}\text { 年 } \\
\text { 勇 }\end{array}$} & \multirow{2}{*}{ 㿑 } & \multirow{2}{*}{ 回 } & \multicolumn{2}{|c|}{ 状 } & & 過 & \multirow{2}{*}{ 定 } \\
\hline & & & & & & & & 拄: & （菌） & 現 & （菌） & \\
\hline \multirow{3}{*}{ 江! } & \multirow{2}{*}{ x } & & 0 姉 & $\hat{o}$ & 58 & $\mathrm{~T} \cdot \mathrm{M}$ & $\begin{array}{r}\because 15 \\
495\end{array}$ & 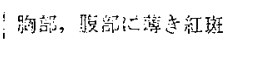 & $(-)$ & 䆓化なし & $(-)$ & 蒩 效 \\
\hline & & & ○源 & ò & 40 & T. $\mathrm{M}$ & $\times 13$ & 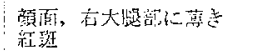 & $(-)$ & 秋化云し & $(\rightarrow)$ & 拈 效 \\
\hline & 1 & & $O$ 音 & $\hat{o}$ & 53 & N T. N & $\begin{array}{r}495 \\
495\end{array}$ & 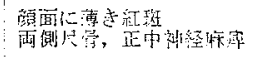 & $(-)$ & 变化令L & $(-)$ & 织 効 \\
\hline \multirow[t]{2}{*}{ 大! } & \multirow[b]{2}{*}{1} & 徯 & ○忠! & $\hat{o}$ & 36 & N T. M & 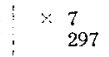 & 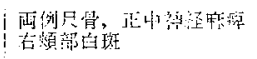 & $(-)$ & 变化新し & $(\rightarrow)$ & 然放 \\
\hline & & & ○弗! & $f$ & 52 & $\mathrm{~N}$ & $\begin{array}{l}\times 14 \\
\quad 462\end{array}$ & 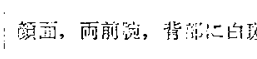 & & 弌化后し & $(-)$ & 無 齐 \\
\hline \multirow[b]{2}{*}{$x$} & \multirow[t]{2}{*}{$x$} & 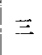 & $0 \div$ & $\underline{\underline{9}}$ & 29 & $\mathrm{~T} \cdot \mathrm{M}$ & $\begin{array}{l}\because 32 \\
1280\end{array}$ & 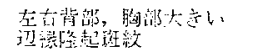 & $(-)$ & 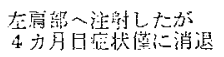 & $(-)$ & 少 效 \\
\hline & & 用 & $\partial$ 铈 & $\hat{o}$ & 38 & $\mathrm{~L}_{2}$ & $\begin{array}{l}29 \\
1060\end{array}$ & 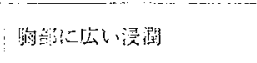 & (it) & 笑化なし & 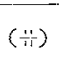 & 䣄 \\
\hline 島 & $\cdot$ & 萖 & 0 炕！ & 우 & 32 & $?$ & $\begin{array}{l}\because 33 \\
1120\end{array}$ & 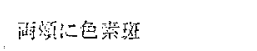 & $(-)$ & 恋化心し & $(-)$ & 烝 效 \\
\hline & I & 苕 & $\mathrm{Q}$ & p & 65 & $\mathrm{~L}_{1}$ & $\cdot 31$ & 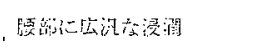 & $(\div)$ & 萧化场し & $(\div)$ & 然放 \\
\hline \multirow{2}{*}{ [S } & $\begin{array}{l}N \\
A\end{array}$ & 孉 & O 㸃 & $\stackrel{\rho}{q}$ & 68 & $L_{2}$ & $\quad 23$ & 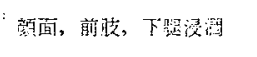 & (it) & 焉化心L & $(+)$ & 泣 坊 \\
\hline & $\mathrm{H}$ & 惊 & D利 & $\hat{o}$ & 44 & $\mathrm{~L}_{2}$ & $\quad \begin{array}{l}31 \\
825\end{array}$ & 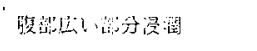 & (4) & 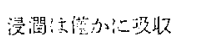 & $\left(\frac{11}{11}\right)$ & 少 就 \\
\hline
\end{tabular}

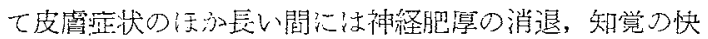

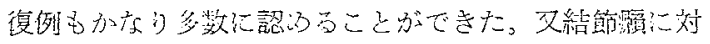

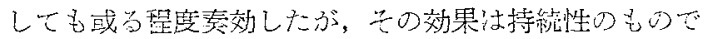

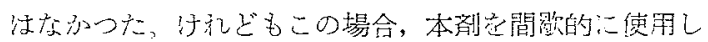

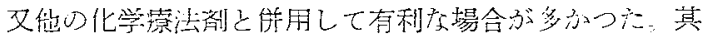

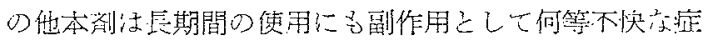

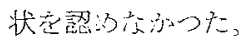

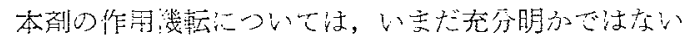

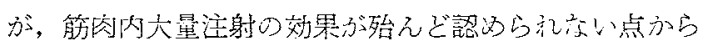

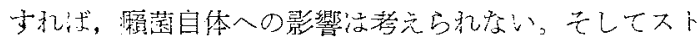
マイ，INAH 等他の抗菌性物質によつて注皮内注射上い

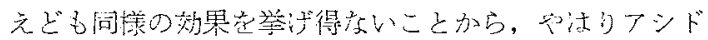

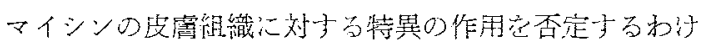

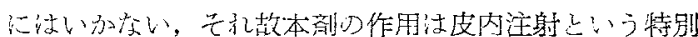

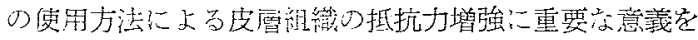

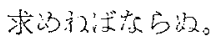

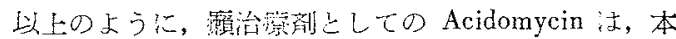

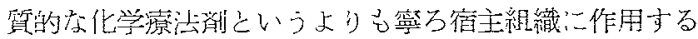

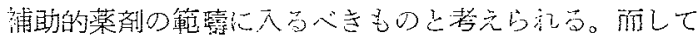

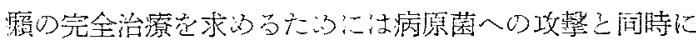

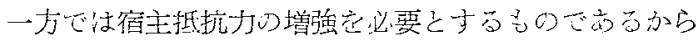

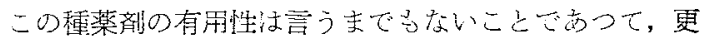

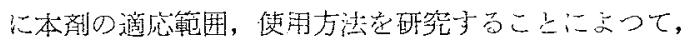

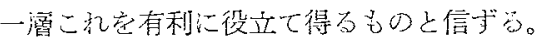

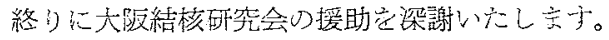




\section{写真 説 明}

Fig. 1 浜 $\bigcirc$ 利，男，17才（青松園）

Fig. 2 同

Fig. 3 青○昌, 男, 27 才 (青松園)

Fig. 4 同

Fig. 5 同

Fig. 6 同

Fig. 7 中○洪, 男, 30才 (青松園)

Fig. 8 间]

Fig. 9 須○菜, 男, 31 字 (青松園)

Fig. 10 同

Fig. 11 船O崟, 男, 49才 (繁生園)

Fig. 12 阔

Fig. 13 宗○宗, 女, 43 才 (愛生園)

Fig. 14 同

Fig. 15 西O猛, 男, 40才 (愛生園)

Fig. 16 同

Fig. 17 高○智, 舅, 46才 (恵楎園)

Fig. 18 同]

Fig. 19 野○鉄，女，30手（青松園）

Fig. 20 同

Fig. 21 三○熊, 男, 64才 (青松園)

Fig. 22 同
1953年6月治療前，頓部結核梾斑紋，大耳神経念珠状肥學。 1957年10月，癷紋消失，大耳神経の肥厚消褪。

1944年 8 月治療前，顔面の隆起せる斑紋。 1957年11月, 顔面隆起斑敉消螁, 僅に褐色斑残名。 1955年 8 月治療前, 胸部の辺縁隆起性珽紋。 1957年11月，殆んぼ吸収，消裉。 1953年 5 月治療前, 背部の浸潤。 1955年 9 月, 湜潤全〈吸収。 1954年 6 月，治療前，顔面の結節，浸潤， 1955年 2 月，結節浸潤はかなりよく䀡収。 1954年10月, 治療前, 頣部の結節。 1955年 8 月, 11力月目に結節著しく吸収。 1954年10月，治療前，顔面結節浸潤， 1957年10月，3年1 力月後，著朋に畩取，ただし周は植も。 1955年 1 月, 治療前, 顏面大結節。 1956年 7 月, 1 年半後, 結節の昅収著し。 1954年.7月沿療前，額，上唇に浸淈性斑紋。

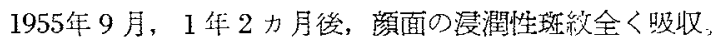
1953年10月, 下腿膝部の板状隆起部切吉泡沫状細胞, 円形細胞 浸潤著明。菌極少数。

1954年9月，治療 1 力年後の昅収部。

1953年10月，背部脏級部の赇片，上皮様細胞中に見られる巨態 細胞, 菌なし。

1954年7月, 治寮10力月の级收部; 


\section{佐谷他諭文附図 (1)}
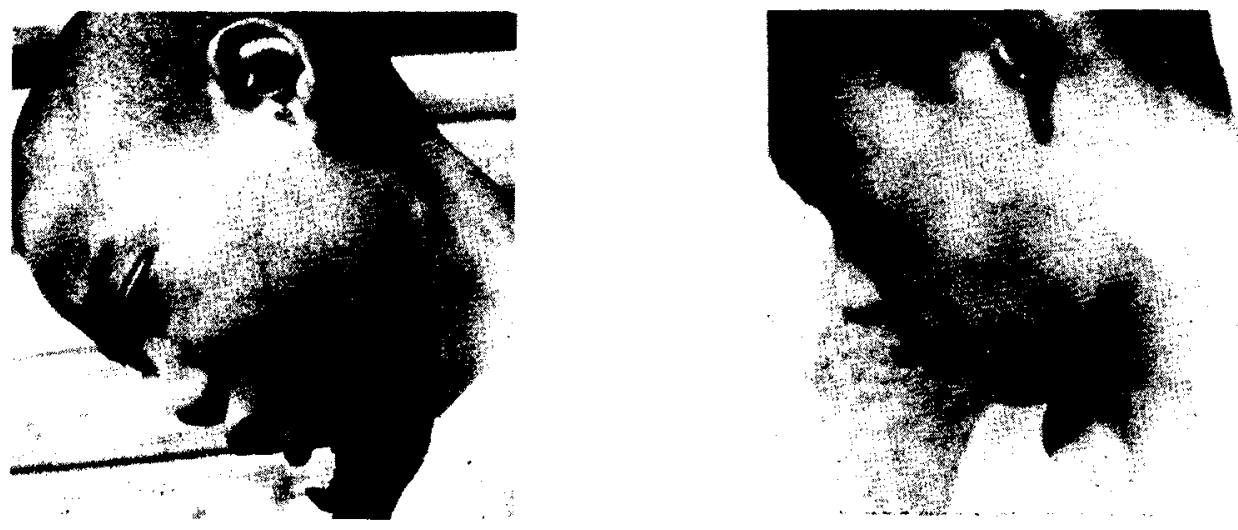

2
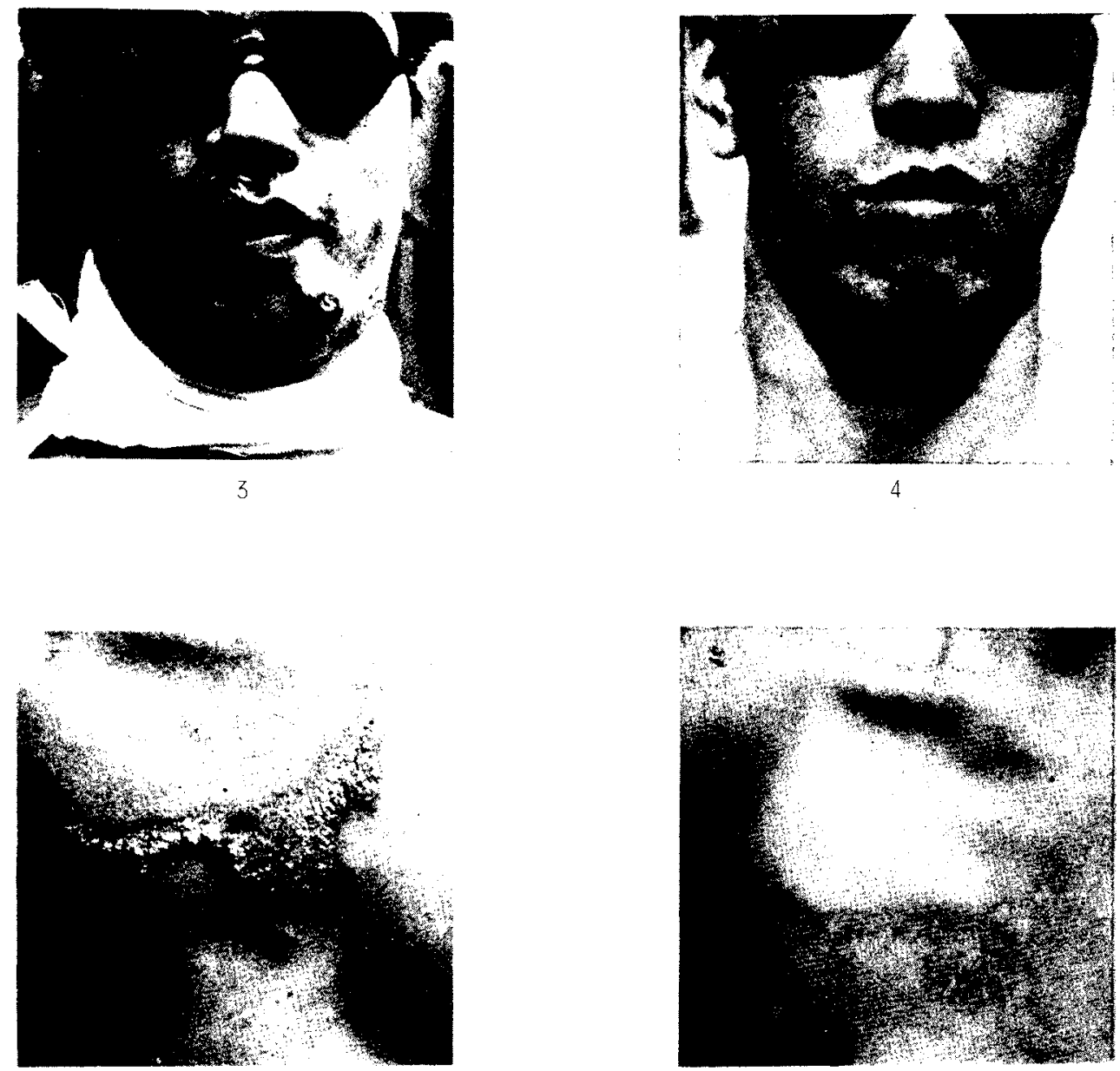


\section{佐，谷他諭文附図 (2)}

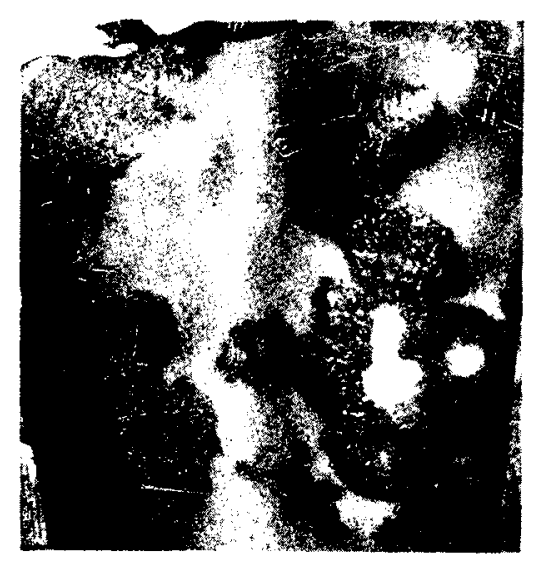

7

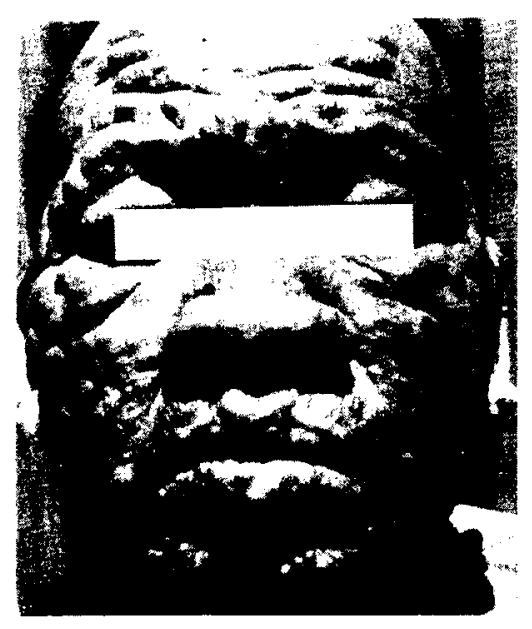

9

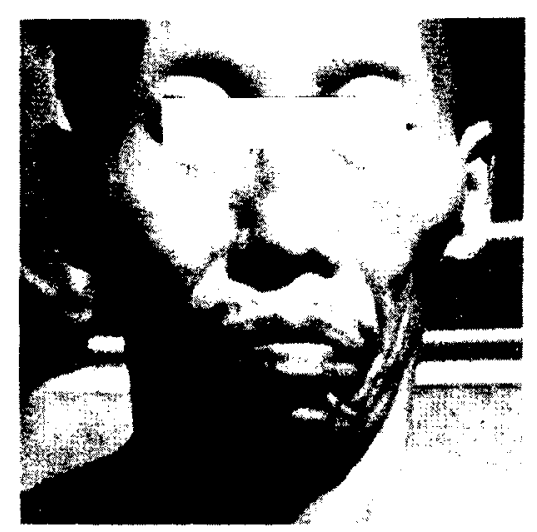

11

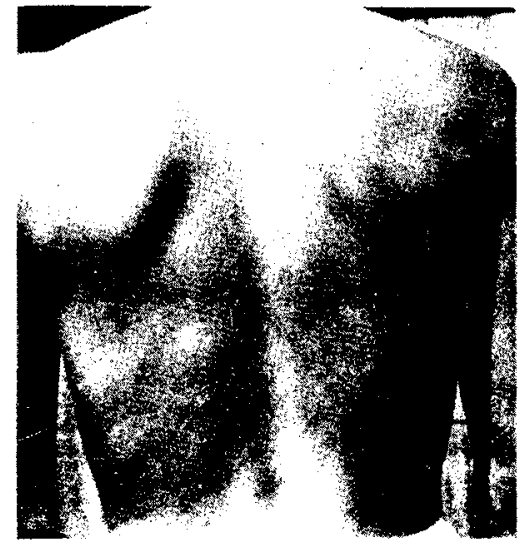

8

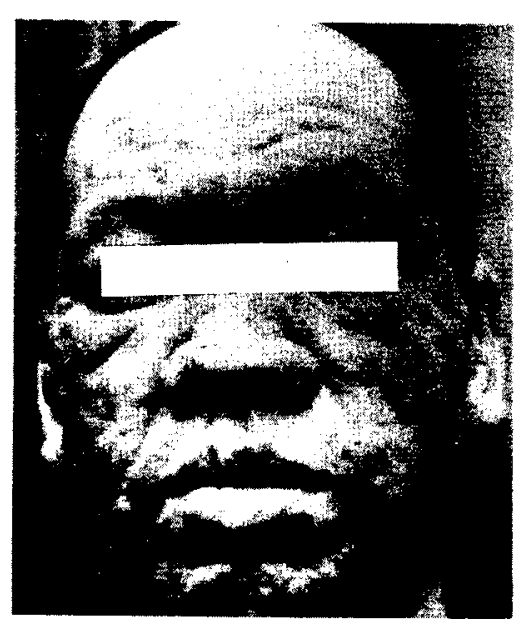

10

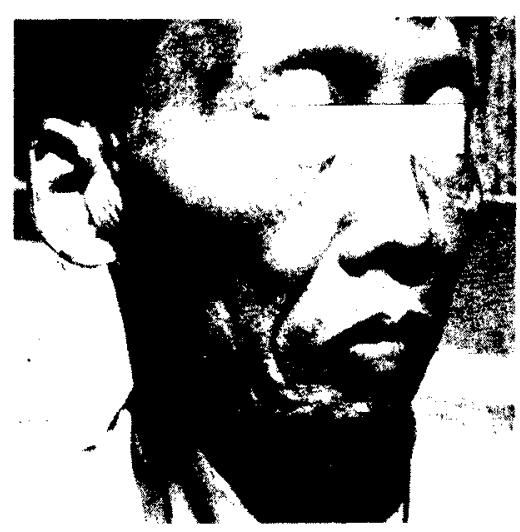

12 
佐谷他論文附図 (3)

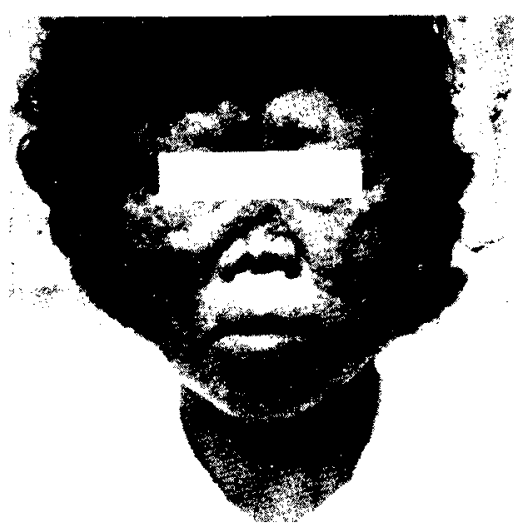

13

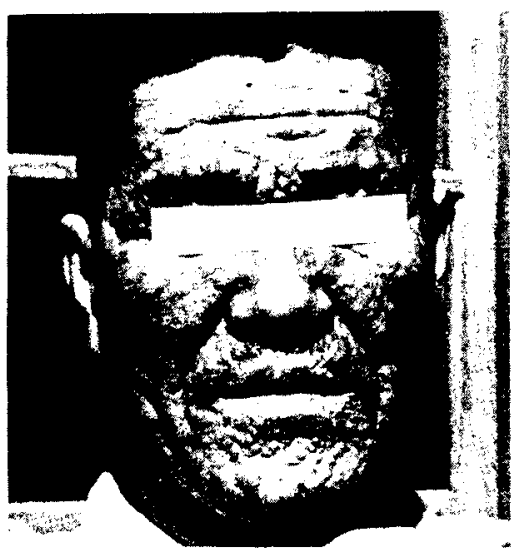

15

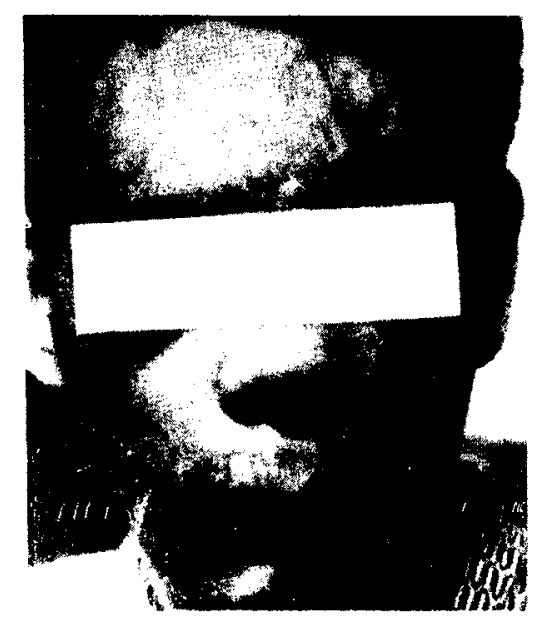

17

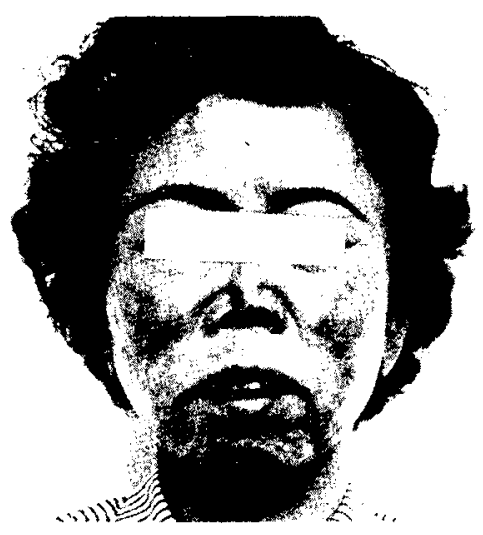

14

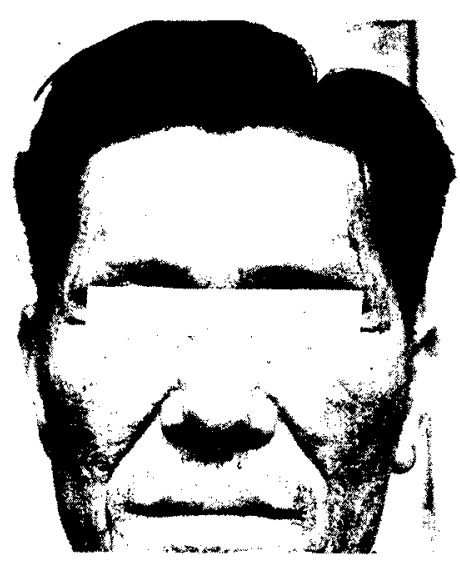

16

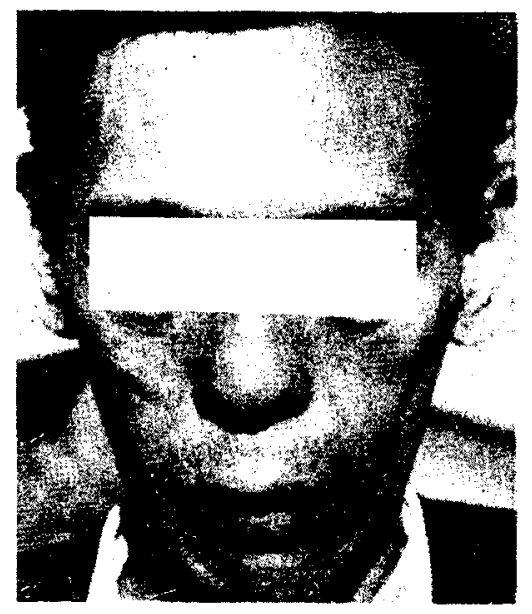

18 


\section{佐谷他論文附図 (4)}

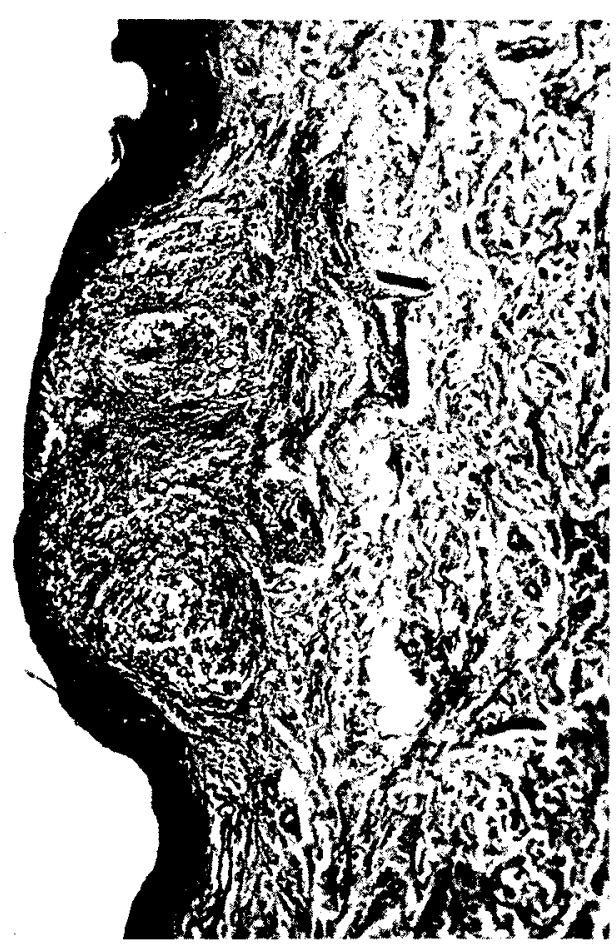

19

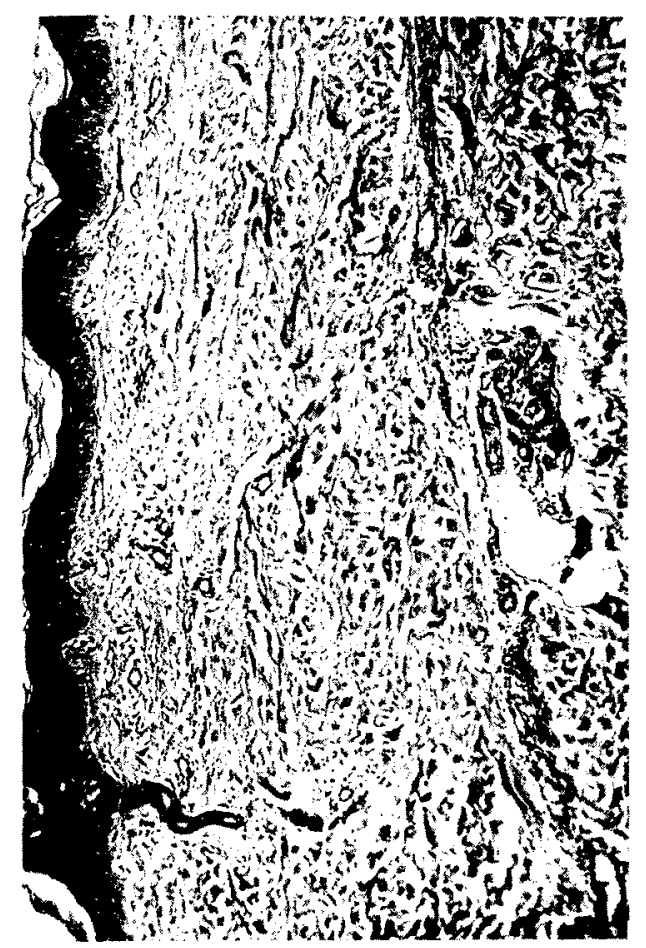

20
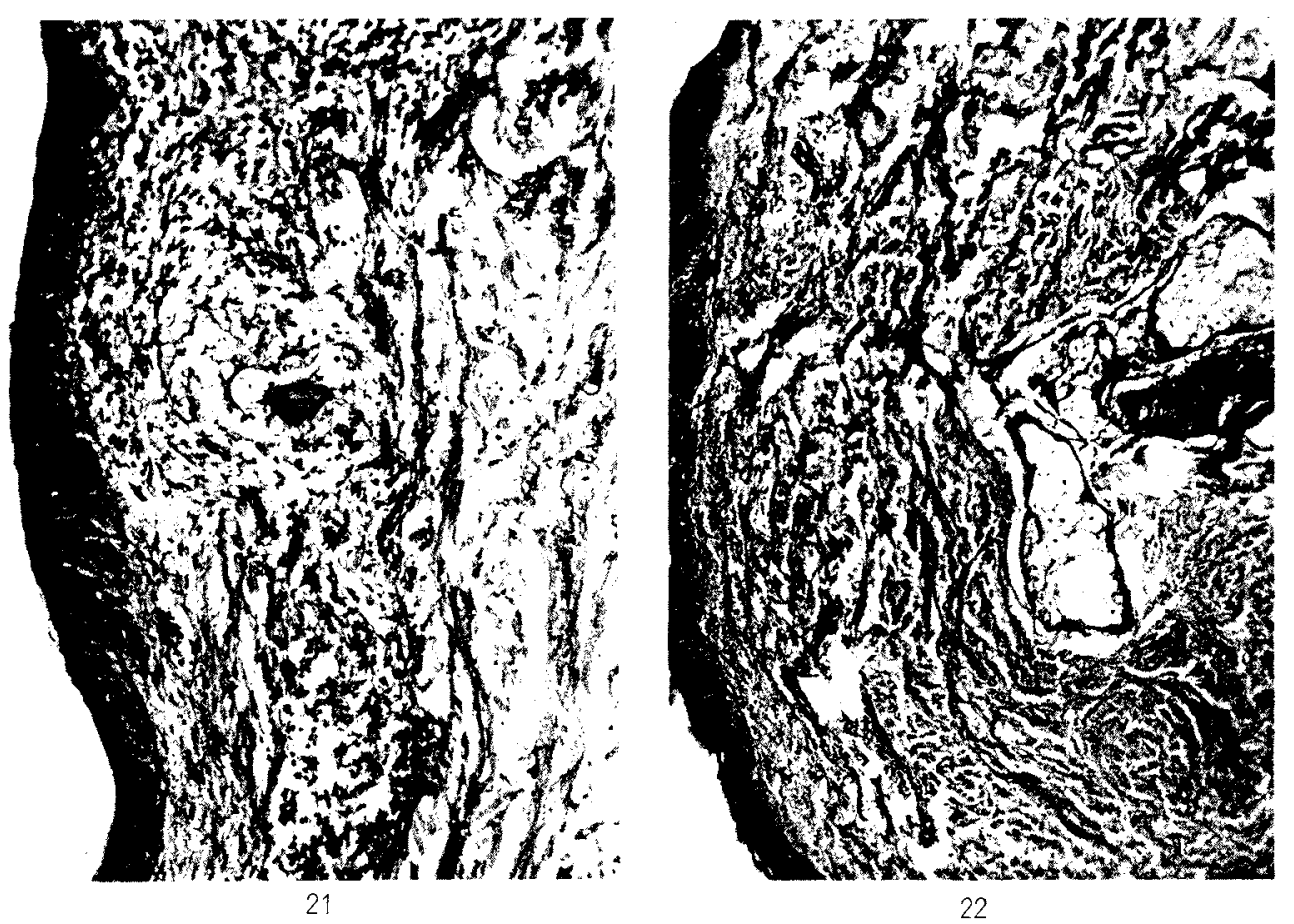


\title{
EPIDEMIOLOGICAL STUDIES ON LEPROSY IN GIFU PREFECTURE
}

\section{VITAL STATISTICS OF LEPROSY PATIENTS}

\author{
Hiroichi KITANO \\ (Ibragi Prefecture Department of Health) \\ (Formorly, Public Health Officer, Gifu Prefecture)
}

The vital statistics of leprosy patients in Gifu prefecture between 1936 and 1955 was studied. Besides the 292 patients reported in a previous paper, 43 patients have been added for a total of 335 (1.2 per 100,000 per year). The rate of incidence is slightly higher than in the previous report but there were no significant alterations epidemiologically.

There wsa a total of 253 deaths, 244 from illness and 9 suicides and the death rate has has dropped sharply in recent years and is one-fourth that of the war years. Mortality was $2.4 \%$. The rate of suicide was $3.8 \%$ and slightly higher than that of the general population. The deaths according to sex has altered since 1945 with a drop in male deaths so that there is no longer a marked difference between male and female deaths (1936 40-1:3.56, 1941 45-1:3.04, 1946 50-1:1.76, 1951 55-1:1.70).

The average age of death was 45.2 years and the there has been a rise of 11.7 years in the 20 year period but in $1951 \sim 55$, it was male, 52.1 years and female, 58.3 years. This prolongation of life coincides with the increase in life span of the Japanese people in general except for effect of the suckling deaths.

There has been an increase of 335 (new cases) against a decrease of 314 (253 deaths, 35 fate unknown, 26 cured or improved) in the 20 year period for a total increase of 21 cases. An increase in the lepromatous type and in female cases has taken place. A marked rise in leprosy in Koreans is also noted. There were 137 cases being treated at home at the beginning of 1936 but has decreased to 24 in 1955 . 